\title{
Foraminiferal Biozonation of Late Eocene - Early Oligocene sediments of BC-1 well, Onshore, Western Niger Delta Basin, Nigeria
}

\author{
${ }^{1}$ AMIEWALAN, FO; ${ }^{2}$ EDEGBAI, JA \\ *Corresponding Author Email: amiewalanflorence@gmail.com, aitalokhai.edegbai@uniben.edu
}

\begin{abstract}
Foraminiferal analysis was carried out on forty (40) ditch cutting samples from BC-1 well in the Onshore, Western Niger Delta at depth intervals of $5590 \mathrm{ft}$ - $8300 \mathrm{ft}$. Lithologic description of the samples together with the gamma ray log analytical data indicated the presence of four lithostratigraphic units composed of shale, sandstone, sandy shale and shaly sand corresponding to the continental Benin and paralic Agbada Formations. A total of twelve (12) species defined into eleven (11) genera, six (6) subfamilies and eleven (11) families were recovered. Benthonic and planktonic foraminiferal species constitute approximately $82 \%$ and $18 \%$ respectively. The calcareous benthics make up $44.4 \%$ while the arenaceous benthics representing $37.7 \%$ of the total foraminiferal assemblages. Foraminiferal index marker species - Globorotalia opima nana, Nonion oyae, Cassigerinella chipollensis and Spiroplectammina wrightii revealed that the age of the studied well is from Late Eocene - Early Oligocene epoch. This indicated that both the planktonic and benthonic foraminiferal recovered from the well contained the transition between the Priabonian and the Rupelian age. Three (3) informal foraminiferal zone were established - Nonion oyae zone, Cassigerinella chipollensis zone and undiagnostic zone. The zones compares with foraminiferal markers species whose stratigraphic ranges are well established in the Niger Delta and globally.
\end{abstract}

DOI: $\underline{\text { https://dx.doi.org/10.4314/jasem.v25i2.24 }}$

Copyright: Copyright $@ 2021$ Amiewalan and Edegbai. This is an open access article distributed under the Creative Commons Attribution License (CCL), which permits unrestricted use, distribution, and reproduction in any medium, provided the original work is properly cited.

Dates: Received: 12 December 2020; Revised: 26 January 2021; Accepted: 12 February 2021

Keyword: Lithostratigraphic units, Agbada Formation, Eocene, Oligocene and Biozone.

The elementary component of biostratigraphy is the biozone, which is the stratigraphical units' defined base on their fossil content. Armstrong and Brasier (2005). The existence of a specific fossil specie in diverse geographic areas infers to the fact that rocks from these areas were deposited at the same times in the earth history. The importance of biozonation in biostratigraphic studies cannot be over emphasized especially for understanding the stratigraphy of the well. A comprehensive biozonation of well sequences is very important for stratigraphic classification of the reservoirs and planning new exploration fronts. Ukpong et al., (2017). Biozonation studies help in the subdivision of well sequence into units that can be correlated with the ages assigned. Biozones may perhaps be acknowledged on local or regional scales and are very significant in the exploration realm, particularly for basin with wide and large scale unit correlations. Giwa et al., (2005). Numerous foraminiferal biozonation studies have been carried out in the Niger Delta basin. Various prominent biozonation studies include the work of Petters (1984), who carried out foraminiferal analysis on Opuama-1 and Opuekeba-1 wells (base of Opuama Shale). Petters (1995) discover from his work that the Akata and Agbada Formations have profuse foraminiferal species. Ozumba and Amojor (1999), proposed six (6) foraminiferal zones (assemblages) for the middle to late Miocene of four (4) well situated in the coastal and central swamp in the western Niger Delta Basin. Obaje and Okosun (2013), carried out planktic foraminiferal biozonation and the correlation of XY-1 Field, Offshore Western Niger Delta. Fadiya et al., (2014), proposed four (4) informal benthonic and younger planktic foraminiferal assemblage zones erected for the studied interval of AM-2 well, Niger Delta Basin. Usman Abubakar (2016), have studied the Late Oligocene to Early Middle Miocene foraminiferal biostratigraphy, sequence stratigraphy and palaeoenvironment of well - 004 (OML - 34) Niger Delta. The planktonic foraminiferal index species recovered from the well shown that the sediments penetrated in the well ranges from Late Oligocene to Early Middle Miocene epoch. Nwaejije et al., (2017), worked on the foraminiferal biostratigraphy and palaeoenvironment of Well 5, OML 34, Niger Delta. Ukpong et al., (2018), carried out analysis on the Foraminiferal Biozonation and Biochronology of Priabonian - Repulian sediments of the Agbada Formation, Niger Delta. The investigation reveals that the planktic and benthic foraminiferal recovered from the sediments were transitional in character. They were used to age date the sediment from Late Eocene (P16/17) to Early Oligocene (P18/19) epoch and 
therefore, indicate the transition between the Priabonian and the Rupelian age. This study integrated both the lithofacies and the index foraminiferal marker species with globally recognized planktic foraminiferal zonation schemes of Bolli and Saunders (1985) in addition with existing benthic foraminiferal zonation schemes of Berggren et al., (1995); Berggren and Pearson (2005); Hernitz Kučenjak, et al., (2006); Wade et al., (2011) and Berggren et al.,(2018) to erect the biozonation and dating the sedimentary sequences penetrated by $\mathrm{BC}-1$ well in the Greater Ughelli
Depobelt, Niger Delta Basin. This study examines the sedimentary units and foraminiferal species of the Late Eocene - Early Oligocene sediment from the Niger Delta Basin. The well (BC-1) used for this research is one of the several developmental boreholes penetrated in the oil-rich Niger Delta, situated Onshore, Niger Delta Basin, Nigeria. It is located in OML 26, a portion of the Greater Ughelli Depobelt in Niger Delta Basin. The geographic coordinates of the studied well is Longitude E5 $5^{0} 33^{\prime} 36^{\prime \prime} .86$ and Latitude N6 ${ }^{0} 18^{\prime} 25^{\prime \prime} .43$. (Fig.1).

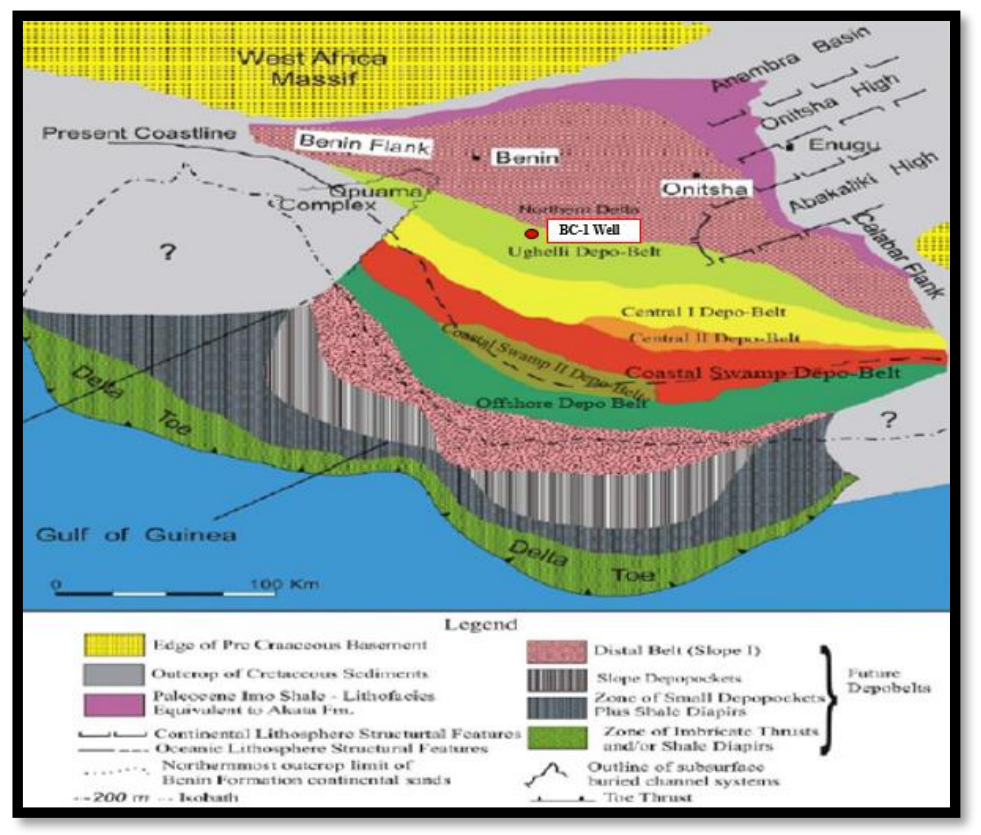

Fig. 1. Regional Structural Elements and Depobelts of the Niger Delta (Modified after Doust and Omatsola (1990); the dot indicates the Location of BC-1 Well).

\section{MATERIALS AND METHODS}

Three hundred and eighty two (382) ditch cutting samples from interval $2900 \mathrm{ft}$. -9650 $\mathrm{ft}$. of a total depth of $6750 \mathrm{ft}$. from BC-1 well were provided by Nigerian Petroleum Development Company (NPDC). Other materials includes sieves, distilled water, water jet, anhydrous sodium carbonate, hot plate, fume cupboard and reflected light binocular microscope.

Lithologic Description: The lithologic description entails thorough description of the ditch cutting samples with the use of reflected binocular microscope to examine the lithology, texture, colour and sorting. $10 \%$ dilute $\mathrm{HCl}$ acid was used on the samples to deduce the presence or absence of calcareous minerals. The lithostratigraphy of the well was established based on lithologic description.
Micropaleontological Sample Processing: Foraminiferal analysis was carried out on forty (40) ditch cutting samples from interval 5,590 ft. - 8,300 ft. The ditch cuttings samples were analysed for their foraminiferal content and other microfaunal accessories using standard foraminiferal preparation technique after Brasier (1980). The sample preparation was in three (3) phases: soaking, wet sieving and drying of residues. About 20 grams of each sample was weighed (using a Mettler PC 440 digital balance) into clean aluminium sample bowls. Depths of samples were correctly transferred into each aluminium sample bowl. Each sample was soaked overnight (24 hours) with anhydrous sodium carbonate and water in a sample jar. Disaggregated samples were wet-sieved through a clean 63 microns sieve with water from a hand directed water jet to remove drilling mud. The residues collected from the sieve was returned into the sample bowls and dried on the hot plate inside a fume cupboard. The dried residue 
was then sieved over 20 and 80 mesh sieves for the different fraction. E.g. coarse, medium and fine fractions, which were then kept in properly branded sample phials and marked with the size fraction for onward micro faunal picking and analysing with reflected light binocular microscope. After picking, identification of the foraminiferal extracted from the samples to genus and specie levels was done by comparing with previously published forms and other relevant foraminiferal literatures. The Strata-Bugs (Biostratigraphy Data Management software) was used to prepare the foraminiferal distribution chart for the studied well. Important foraminiferal bio-events considered that were used for the erection of the biozone include: The method of drilling of the well (Ditch cutting sample) is such that much mixing of materials was possible. Therefore, only the level of first appearance of a species (First Downhole Occurrence (FDO) / Last Appearance Datum (LAD) of chronostratigraphically significant planktic / benthic foraminiferal marker species were noteworthy, the highest level in the well, for lower appearances (LDO / FAD may purely be the effect of mixing / caving-in. Foraminiferal abundance and diversity peaks dated with foraminiferal markers species whose stratigraphic ranges are well established in the Niger Delta and worldwide.

\section{RESULTS AND DISCUSSION}

Lithology, sand/shale ratios, wireline log (Gamma ray) has assisted in the subdivision of the lithostratigraphy of the wells into Benin and Agbada
Formations. The lithostratigraphy of the well reveals both the continental and paralic sequences of Benin and Agbada Formations. The continental sequence (2900 ft. - 7075 ft.): Entails mainly sandstone sediment intercalating with thin layers of shaly sand, sandy shale and shale beds of coarsening upward sequence. This is in line with the work of Esan (2002), who opined that the Benin Formation consists of fluviatile sands with clay and shale/mudstone interbeds. The sandstone are fine to medium grained, subangular to subrounded, moderately sorted with mica flakes, carbonaceous detritus, considerably ferruginized. The paralic sequence (7075 ft. - $9650 \mathrm{ft}$.): Consists of alternation of sandstone, shaly sand, sandy shale and shale beds deposited in both the marginal marine to Delta front setting. This come to an agreement with the work of Short and Stauble (1967). They posited that the Agbada Formation is characterized by the alternation of sandstone and sand bodies with shale layers. Weber (1971), had specified that the deposition of alternating sandstone and mudstone units occurs through relative sea level rise and fall. The mudstone units within the Agbada Formation were largely laid down during phases of relative sea level rise (transgressive events), while the sandstone units are typically related with phases of relative sea-level fall (regressive events). The sandstone are fine to medium grained, subangular, subrounded to rounded, moderately to well sorted with mica flakes, rare ferruginized. The shales are light grey and light brown, subfissile to fissile, mostly hard to moderately hard.

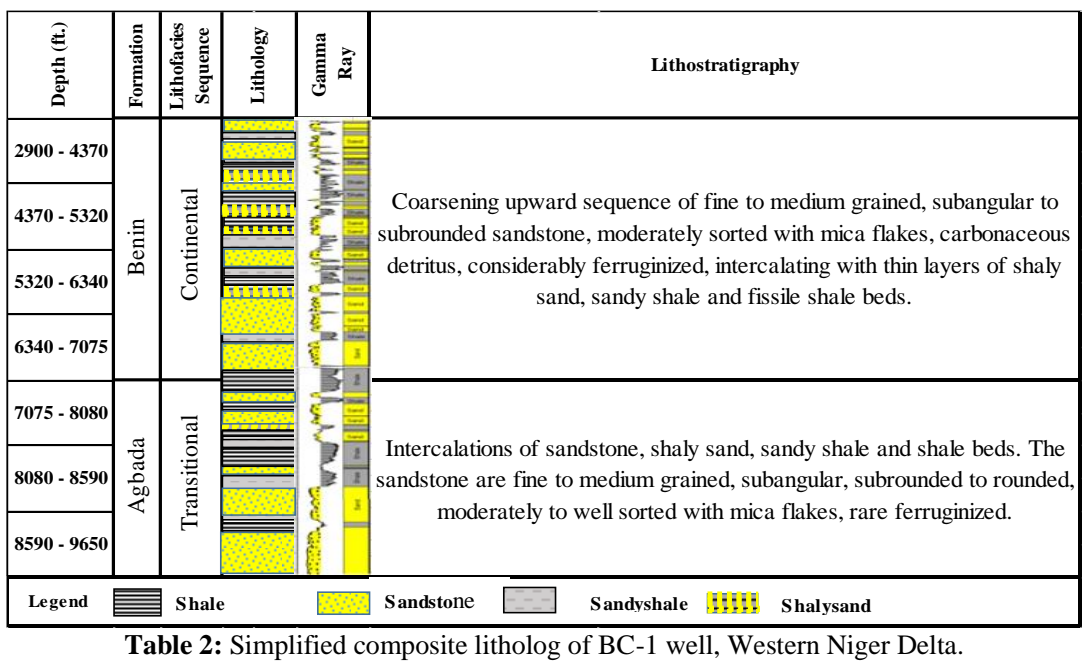

Foraminiferal Distribution in the study well: are categorised by rare planktic foraminiferal (FOP) Foraminiferal assemblage over the interval was generally poor with some barren intervals. Depth $5590 \mathrm{ft}$. was barren of foraminiferal. Intervals $5590 \mathrm{ft}$. - $6715 \mathrm{ft}$. are characterized by rare recovery of Globorotalia praebulloides, Bathysiphon spp. and Calcareous indeterminate. Intervals 6715 ft. - $8300 \mathrm{ft}$. and was dominated by benthonic foraminiferal. Generally most of the species recorded are calcareous and arenaceous benthic foraminiferal species. Planktic species are rare / absent in the well. The FOP shows that Globorotalia opima nana, Cassigerinella chipollensis and planktonic indeterminate have spot 
occurrence whereas Globigerina praebulloides, Globigerina spp. have short stratigraphic ranges. For the benthonic foraminiferal, some species have spot occurrence (Spiroplectammina wrightii, Bulimina elongata, Textularia erlandi and Arenaceous indeterminate) while others (Nonion oyae, Bathysiphon spp., Verneulina spp., Haplophragmoides spp. and Lagena spp.) are restricted to a particular depth ranges. Twelve species recovered were defined into eleven genera, six subfamilies and eleven families. The total count of foraminiferal described from the well is forty five (45) comprising of twenty (20) calcareous benthic (44.4 $\%)$, seventeen (17) arenaceous benthic (37.7\%) and eight (8) planktic (17.7\%). Benthonic (Calcareous and
Arenaceous) and planktic foraminiferal species constitute approximately $82 \%$ and $18 \%$ respectively. Tables 3 shows the different foraminiferal count recovered from the well. Table 4 shows the percentage values and count of the different types of foraminiferal in study well. Fig. 2 displays the pie chart plot of the percentage of the different foraminiferal recovered while fig. 3 illustrates the pie chart plot of the percentage of the different benthic foraminiferal recovered in the well. Fig. 4 indicates the foraminiferal abundance, diversity pattern, important foraminiferal events and paleo water depth established in the well. Plate 1 shows photomicrographs of selected foraminiferal species from the study well.
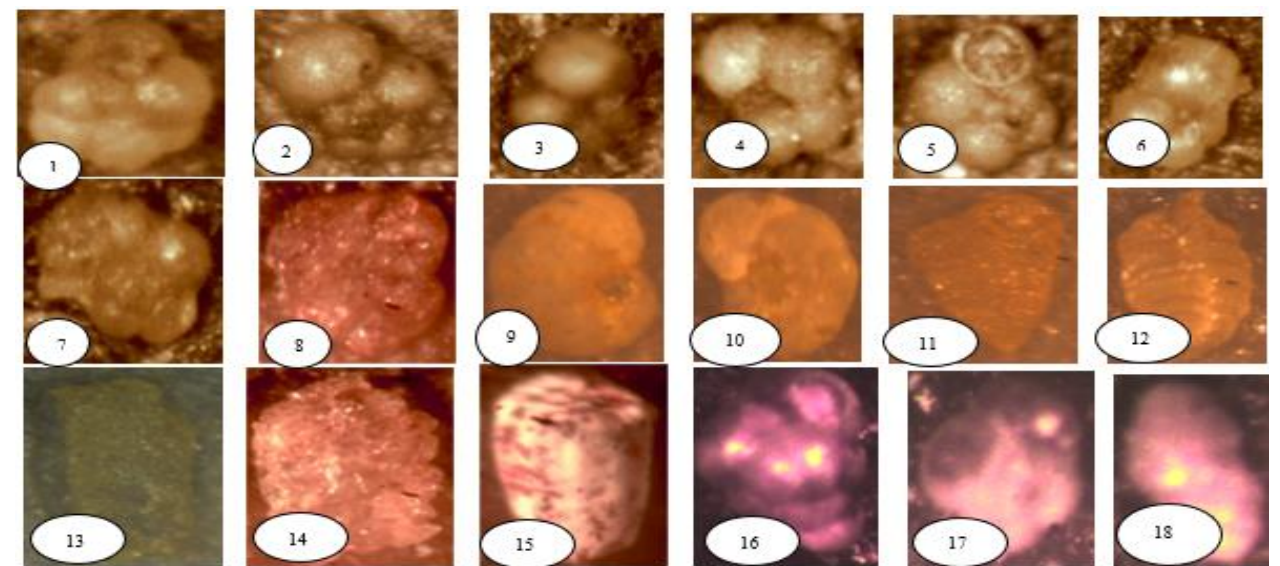

Plate I: Photomicrographs of selected foraminiferal specie from the study well

Explanation of Plate I: 1. Cassigerinella chipollensis 2. Globigerina praebulloides (spiral side) 3. Globigerina praebulloides (umbilical side) 4. Globorotalia opima nana (umbilical side) 5. Globorotalia opima nana (spiral side) 6. Globigerina spp. (umbilical side) 7. Globigerina spp. (spiral side) 8. Haplophragmoides spp. 9. Nonion oyae (umbilical side) 10. Nonion oyae (spiral side) 11. Spiroplectammina wrightii 12. Textularia earlandii 13. Bathysiphon spp. 14. Arenaceous indeterminate 15. Calcareous indeterminate 16. Bulimina elongata 17. Planktic indeterminate 18. Verneulina spp.

Table 3: shows the different foraminiferal count recovered from the well.

\begin{tabular}{llllll}
\multicolumn{6}{c}{ Table 3: shows the different foraminiferal count recovered from the well. } \\
\hline $\begin{array}{l}\text { Calcareous Assemblages } \\
\text { (FOBC) }\end{array}$ & $\begin{array}{l}\text { Total } \\
\text { Count }\end{array}$ & $\begin{array}{l}\text { Arenacoes Assemblages } \\
\text { (FOBA) }\end{array}$ & $\begin{array}{l}\text { Total } \\
\text { Count }\end{array}$ & $\begin{array}{l}\text { Planktonic Assemblages } \\
\text { (FOP) }\end{array}$ & $\begin{array}{l}\text { Total } \\
\text { Count }\end{array}$ \\
\hline Calcareous Indeterminate & 8 & Arenaceous indeterminate & 4 & Planktic indeterminate & 1 \\
Nonion oyae & 2 & Spiropletamina wrightii & 1 & Globigerina praebulloides & 2 \\
Bulimina elongate & 1 & Haplophragmoides spp. & 4 & Cassigerinalla chipollensis & 1 \\
Lagena spp. & 9 & Textularia erlandi & 1 & Globigerina spp. & 3 \\
Total & $\mathbf{2 0}$ & $\begin{array}{l}\text { Bathysiphon } \text { spp. } \\
\text { Verneulina } \text { spp. }\end{array}$ & 3 & Globorotalia opima nana & 1 \\
& & Total & $\mathbf{1 7}$ & Total & $\mathbf{8}$ \\
\hline
\end{tabular}

Table 4: The percentage values and count of the different types of foraminiferal in study well.

\begin{tabular}{lccccc}
\hline Types of Foraminiferal & $\begin{array}{l}\text { Planktic assemblages } \\
\text { (FOP) }\end{array}$ & $\begin{array}{l}\text { Calcareous } \\
\text { (FOBC) }\end{array}$ & assemblages & $\begin{array}{l}\text { Arenaceous assemblages } \\
\text { (FOBA) }\end{array}$ \\
Foraminiferal Count & 8 & 20 & 17 \\
Percentage value & 17.7 & 44.4 & 37.7 \\
\hline
\end{tabular}

Planktonic foraminiferal recovered in the well: Four (4) species belonging to three (3) genera, families and two (2) subfamilies were identified. Species diversity was low. The common species was Globigerina spp. Other important species are the Globigerina praebulloides, Cassigerinella chipollensis,
Globorotalia opima nana and planktic indeterminate. FOP count in the well is shown in table 3. A pic chart plot representing the percentage of the different foraminiferal assemblage is shown in fig. 2. 


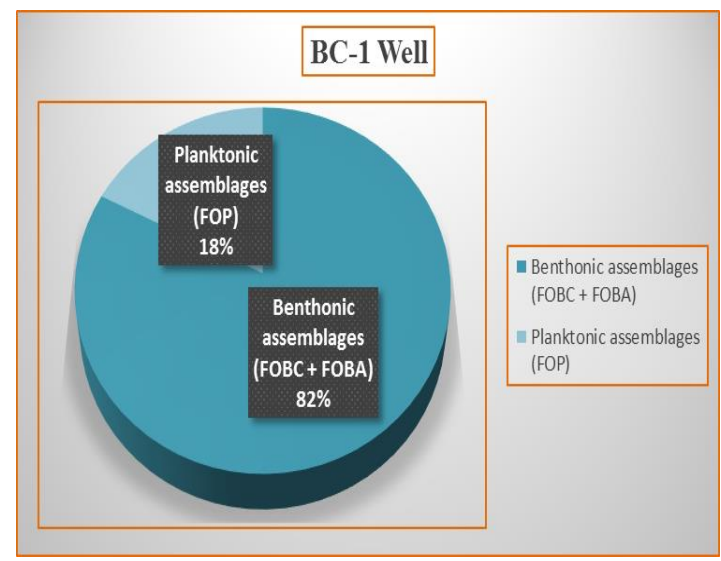

Fig. 2: Pie chart plot showing the percentage of the different foraminiferal recovered in $\mathrm{BC}-1$ well.

Benthonic foraminiferal recovered in the well Eight (8) species, from eight (8) families, four (4) subfamilies and eight (8) genera were recovered. From this, the FOBC constitute three (3) species, defined into three (3) genera, one (1) subfamily and three (3) families whereas the FOBA consists of five (5) species outlined into five (5) genera, three (3) subfamilies and five (5) families. The FOBC were dominated by Lagena spp. and the Calcareous indeterminate. The remaining species have rare occurrences. The FOBA were dominated by Haplophragmoides spp., Verneulina spp. and Arenaceous indeterminate. Others include Spiroplectammina wrightii, Textularia erlandi and Bathysihpon spp. The diversity is generally low with very poor frequency. A pic chart plot representing the percentage of the different benthics foraminiferal assemblage is shown in fig. 3. FOBC and FOBA counts are shown in table 3.

Age determination: Foraminiferal index marker species (Cassigerinella chipollensis, Globorotalia opima nana, Nonion oyae and Spiroplettamina wrightii) recovered were used for age dating of the well.

Intervals between $7405 \mathrm{ft}$ - $8300 \mathrm{ft}$. was defined by the FDO of Nonion oyae at $7405 \mathrm{ft}$. and Globorotalia opima nana at $7465 \mathrm{ft}$. These index markers species enabled the assigned age of Late Eocene to this intervals of the well section. Toumarkine and Luterbacher (1985), had used the presence of Catapsydrax dissimilis and Globorotalia opima nana to assigned the age between P15 (because of the absence of Truncorotaloides rohri) and the P20 zones of late Eocene to Early Oligocene age. Fadiya et al., (2014), used the occurrence of the benthic foraminiferal species.

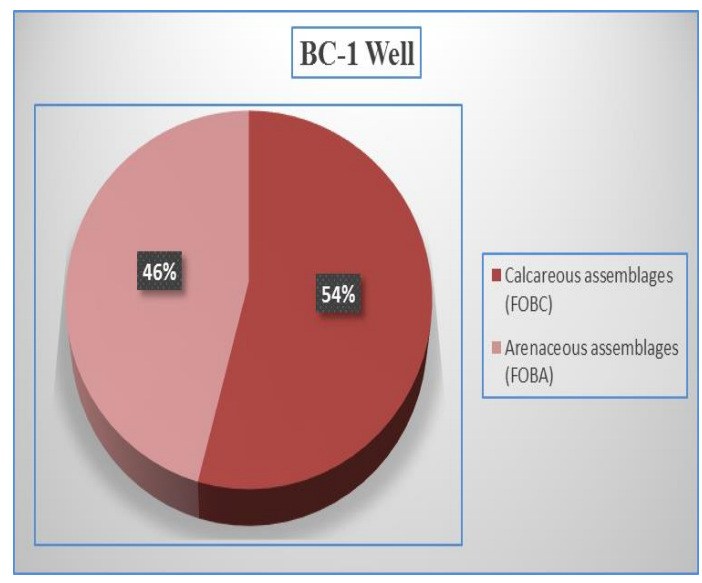

Fig. 3: Pie chart plot showing the percentage of the different benthic foraminiferal recovered in $\mathrm{BC}-1$ well.

Hopkinsina hourqi and Nonion oyae to age date Middle to Late Eocene in the Foraminiferal biostratigraphy and palaeoenvironment of sediments from well AM-2, Niger Delta. This interval is coeval to (P16/P17): Turborotalia cerroazulensis zone of Bolli and Saunders, (1985); (P15 - P17): Po. Semiinvoluta - T. cerroazulensis zone of Berggren et al., (1995); (E14 - E16): G. Semiinvoluta - H. alabamensis zone of Berggren and Pearson (2005); (E14 - E16): G. Semiinvoluta - H. alabamensis zone of Hernitz Kučenjak et al., (2006); (E15 - E16): G. Index - H. alabamensis zone of Wade et al., (2011) and (E15 - E16): G. Index - H. alabamensis zone of Berggren et al., (2018).

The age of the intervals between $6715 \mathrm{ft}$. $-7405 \mathrm{ft}$. was defined by the FDO of Cassigerinella chipollensis at $6715 \mathrm{ft}$. and Spiroplectamima wrightii at $7195 \mathrm{ft}$. These index marker species are characteristic marker for Early Oligocene and were used to assigned period of Early Oligocene to this interval. Although, Sexton et al., (2006) and Huber et al., (2006), assigned (Upper Eocene zone E14) and (Upper Eocene Zone E15/16) with the presence of Cassigerinella chipollensis in their works, the genus Cassigerinella was formerly understood to be constrained to the Oligocene and early Miocene. The first appearance of Cassigerinella chipollensis was suggested as a marker specie for the basal Oligocene (Blow and Banner, 1962). Conversely Saito and Bé (1963), detected varieties of Cassigerinella in the Eocene. Later, Cordey (1968a), established it but he distinguished them at the species level as Cassigerinella eocaenica based on the marginally smaller size and a smaller amount of inflated chambers, flatter enrollment and less rounded periphery. Consequently it turn into a characteristic presentation for workers to refer Oligocene specimens 
to chipollensis and Eocene specimens to eocaenica. Other workers such as Nayak and Singh (2011); Farouk et al., (2015) and Pearson et al., (2018b), used Cassigerinella chipollensis as a marker specie for Early Oligocene age. Adeniran (1997), used the extinction point of Globigerina ciperoensis and Cassigerinella chipollensis to delineate the Oligocene - Miocene boundary. Petters (1982), submitted that index foraminiferal taxa such as Hopkinsina bononiensis, Spiroplectamima wrightii, Uvigerinella sparsicostata, Lenticulina grandis, Bolivina imperatix and Hopkinsina bononiensis are an Early Oligicene Miocene forms. Loeblich and Tappan (1988), assigned a Lower Paleocene to Oligocene age to Spiroplectammina wrightii. Ukpong (2017), used the LDO of Spiroplectammina wrightii as an index marker for the Early Oligocene epoch in Sequence Stratigraphic Analysis of Well -X2 in the Niger Delta, South Eastern Nigeria. This interval relates with (P18 (P19): Globorotalia opima opima - Cassigerinella chipollensis/Pseudohastigerina micra zone of Bolli and Saunders, (1985); (P18 - P21a): Ch. cubensis Pseudohastigerina spp. - Gl. angulisuturalis/Ch. cubensis zone of Berggren et al., (1995); (O1 - O4): P. naguewichiensis - Gl. angulisuturalis/Ch. cubensis zone of Berggren and Pearson (2005); (O1 - O4): P. naguewichiensis - Gl. angulisuturalis/Ch. cubensis zone of Hernitz Kučenjak et al., (2006); (O1 - O4): P. naguewichiensis - Gl. angulisuturalis/Ch. cubensis zone of Wade et al., (2011) and (O1 - O4): P. naguewichiensis - C. angulisuturalis/Ch. cubensis zone of Berggren et al., (2018).

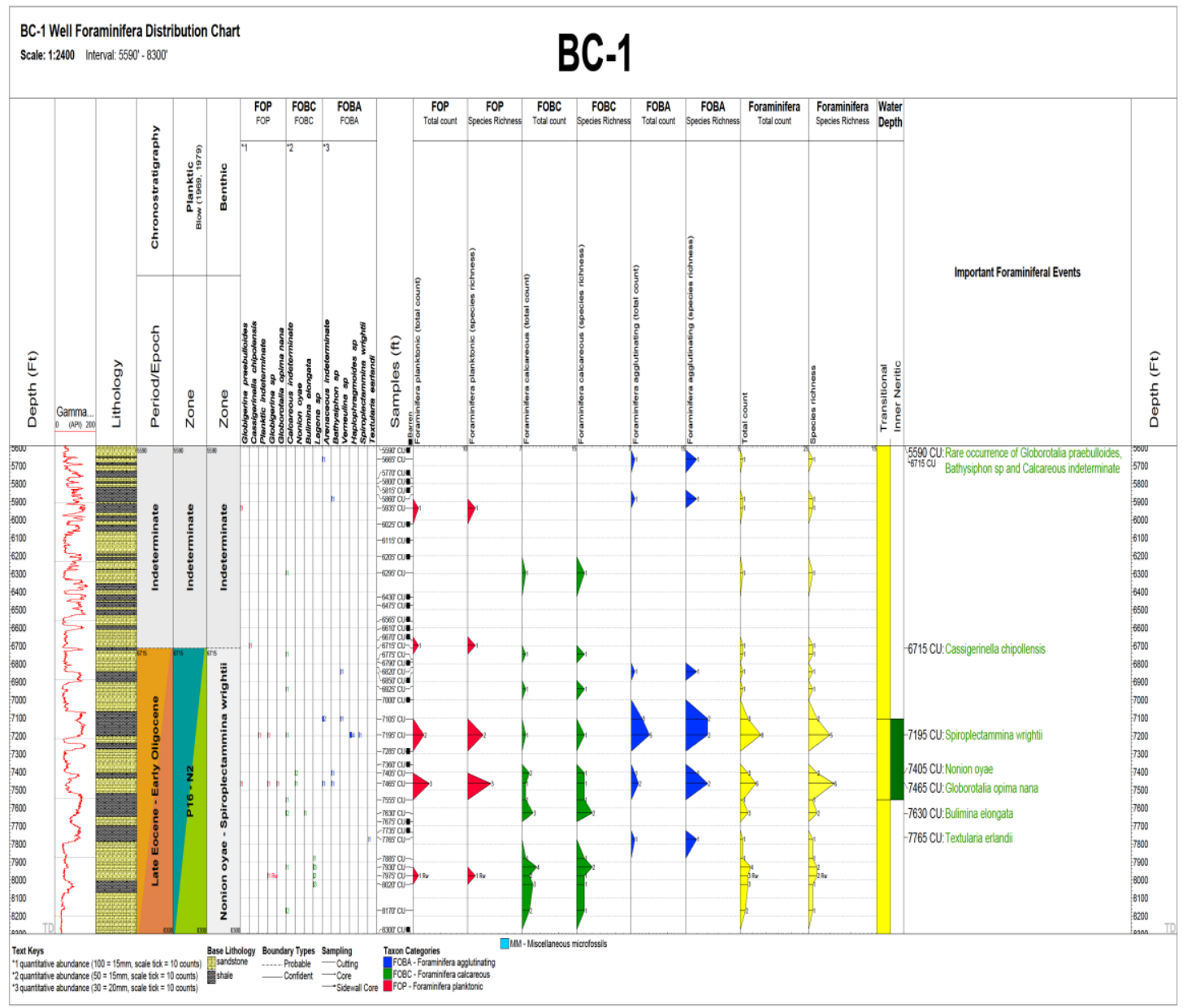

Fig 4: Shows the foraminiferal abundance, diversity pattern, important foraminiferal events and paleo water depth established in BC-1 well.

From the abovementioned species, in comparism with other previous researchers, FDO of Nonion oyae at $7405 \mathrm{ft}$. and Globorotalia opima nana at $7465 \mathrm{ft}$. were used to assigned late Eocene epoch. The FDO of Spiroplectammina wrightii at $7195 \mathrm{ft}$. was used to date Early Oligocene epoch and the FDO of Cassigerinella chipollensis at $6715 \mathrm{ft}$. was used to delineate the Oligocene - Miocene boundary in this present study. The age of the intervals $5590 \mathrm{ft}$. - $6715 \mathrm{ft}$. was indeterminate due to the absence of index maker specie. The age of the studied section of the well has 
been interpreted to belong to Late Eocene - Early

Oligocene epoch. Table 5.

Table 5: The age and biozones established in BC-1 well using foraminiferal marker species. Correlated with zonal scheme demarcated by Bolli and Saunders (1985); Berggren et al., (1995); Berggren and Pearson (2005); Hernitz Kučenjak, et al., (2006); Wade et al., (2011) and Berggren et al.,(2018).

\begin{tabular}{|c|c|c|c|c|c|c|c|c|c|c|}
\hline $\begin{array}{l}\text { Depth } \\
\text { interv } \\
\text { al (ft.) }\end{array}$ & $\begin{array}{l}\mathrm{Ag} \\
\mathrm{e}\end{array}$ & $\begin{array}{l}\text { Epoc } \\
\mathrm{h} / \text { Per } \\
\text { iod }\end{array}$ & $\begin{array}{l}\text { Foraminiferal } \\
\text { zone Bolli and } \\
\text { Saumders } \\
(1985)\end{array}$ & $\begin{array}{l}\text { Foraminife } \\
\text { ral zone } \\
\text { Berggren } \\
\text { et al., } \\
(1995)\end{array}$ & $\begin{array}{l}\text { Foraminife } \\
\text { ral zone } \\
\text { Berggren } \\
\text { and } \\
\text { Pearson } \\
(2005) \\
\end{array}$ & $\begin{array}{l}\text { Foraminife } \\
\text { ral zone } \\
\text { Hernitz } \\
\text { Kučenjak } \\
\text { et al., } \\
(2006)\end{array}$ & $\begin{array}{l}\text { Foraminife } \\
\text { ral zone } \\
\text { Wade et } \\
\text { al., (2011) }\end{array}$ & $\begin{array}{l}\text { Foraminife } \\
\text { ral zone } \\
\text { Berggren } \\
\text { et al., } \\
(2018)\end{array}$ & $\begin{array}{l}\text { Biozonati } \\
\text { on for } \\
\text { this study }\end{array}$ & $\begin{array}{l}\text { Significant } \\
\text { Foraminife } \\
\text { ral datums }\end{array}$ \\
\hline $\begin{array}{l}6715 \\
- \\
7405\end{array}$ & $\begin{array}{l}\mathrm{Ru} \\
\text { pel } \\
\text { ian }\end{array}$ & $\begin{array}{l}\text { Early } \\
\text { Olig } \\
\text { ocen } \\
\text { e }\end{array}$ & $\begin{array}{l}\text { (P18 /P19): } \\
\text { Globorotalia } \\
\text { opima opima - } \\
\text { Cassigerinella } \\
\text { chipollensis/Pse } \\
\text { udohastigerina } \\
\text { micra }\end{array}$ & $\begin{array}{l}\text { (P18 - } \\
\mathrm{P} 21 \mathrm{a}) \text { : Ch. } \\
\text { cubensis - } \\
\text { Pseudohas } \\
\text { tigerina } \\
\text { spp. - Gl. } \\
\text { angulisutu } \\
\text { ralis/Ch. } \\
\text { cubensis }\end{array}$ & $\begin{array}{l}(\mathrm{O} 1-\mathrm{O} 4) \text { : } \\
P . \\
\text { naguewich } \\
\text { iensis - Gl. } \\
\text { angulisutu } \\
\text { ralis/Ch. } \\
\text { cubensis }\end{array}$ & $\begin{array}{l}(\mathrm{O} 1-\mathrm{O} 4) \text { : } \\
P . \\
\text { naguewich } \\
\text { iensis }- \text { Gl. } \\
\text { angulisutu } \\
\text { ralis/Ch. } \\
\text { cubensis }\end{array}$ & $\begin{array}{l}(\mathrm{O} 1-\mathrm{O} 4) \\
P . \\
\text { naguewich } \\
\text { iensis }- \text { Gl. } \\
\text { angulisutu } \\
\text { ralis/Ch. } \\
\text { cubensis }\end{array}$ & $\begin{array}{l}(\mathrm{O} 1-\mathrm{O} 4): \\
P . \\
\text { naguewich } \\
\text { iensis - C. } \\
\text { angulisutu } \\
\text { ralis/Ch. } \\
\text { cubensis }\end{array}$ & $\begin{array}{l}\text { Casigerin } \\
\text { ella } \\
\text { chipollen } \\
\text { sis }\end{array}$ & $\begin{array}{l}\text { FDO/LAD } \\
\text { of } \\
\text { Cassigerin } \\
\text { ella } \\
\text { chipollensi } \\
s \text { at } 6715 \\
\mathrm{ft} .\end{array}$ \\
\hline $\begin{array}{l}7405 \\
- \\
8300\end{array}$ & $\begin{array}{l}\text { Pri } \\
\text { ab } \\
\text { oni } \\
\text { an }\end{array}$ & $\begin{array}{l}\text { Late } \\
\text { Eoce } \\
\text { ne }\end{array}$ & $\begin{array}{l}\text { (P16/P17): } \\
\text { Turborotalia } \\
\text { cerroazulensis }\end{array}$ & $\begin{array}{l}\text { (P15 - } \\
\text { P17): Po. } \\
\text { Semiinvolu } \\
\text { ta - T. } \\
\text { cerroazule } \\
\text { nsis }\end{array}$ & $\begin{array}{l}\text { (E14 - } \\
\text { E16): G. } \\
\text { Semiinvolu } \\
\text { ta - H. } \\
\text { alabamens } \\
\text { is }\end{array}$ & $\begin{array}{l}\text { (E14 - } \\
\text { E16): G. } \\
\text { Semiinvolu } \\
\text { ta - H. } \\
\text { alabamens } \\
\text { is }\end{array}$ & $\begin{array}{l}\text { (E15 }- \\
\text { E16): } \quad G . \\
\text { Index }-H . \\
\text { alabamens } \\
\text { is }\end{array}$ & $\begin{array}{l}\text { (E15 }- \\
\text { E16): } \quad G . \\
\text { Index }-H . \\
\text { alabamens } \\
\text { is }\end{array}$ & $\begin{array}{l}\text { Nonion } \\
\text { oyae }\end{array}$ & $\begin{array}{l}\text { FDO/LAD } \\
\text { of Nonion } \\
\text { oyae at } \\
7405 \mathrm{ft} \text {. }\end{array}$ \\
\hline
\end{tabular}

$\begin{array}{ll}\text { FDO: First Downhole Occurrence } & \text { LAD: Last Apperance Date } \\ \text { Table } 4 \text { shows the age stratigraphic intervals based on the First Downhole Occurrence (FDO) of the marker }\end{array}$ species recovered from the well.

Biozonation: The foraminiferal zonation of the well was guided by the earlier works of Bolli and Saunders (1985) and the work of Berggren et al., (2018). Though planktic foraminiferal species were generally rare/absent in the well, benthic foraminiferal species whose stratigraphic distributions that is well established in the Niger Delta have been calibrated with planktic foraminiferal species which were used to assigned ages and zonation in this Well. Foraminiferal species used to title biozones was based on the occurrences of age diagnostic planktic/benthic taxa assemblages.

Zonal characteristic of Nonion oyae zone

Stratigraphic interval: $7405 \mathrm{ft}$ - $8300 \mathrm{ft}$.

Equivalent planktic foraminiferal zone: (P16/P17): Turborotalia cerroazulensis; (E15 - E16): G. Index H. alabamensis

Age: Late Eocene (Priabonian).

Significant microzone events: FDO of Nonion oyae at $7405 \mathrm{ft}$. and co-occurrence of Globorotalia opima nana at $7460 \mathrm{ft}$.

Definition: The top is marked by the FDO of Nonion oyae and the co-occurrence of Bathysiphon spp. at $7405 \mathrm{ft}$. The base is placed at $8300 \mathrm{ft}$. (the last sample analysed). This interval is characterised by few foraminiferal species. The FOP species recovered in this zone include Globorotalia opima nana, Globigerina praebulloides and Globigerina spp. The FOBC recovered within this zone was dominated by Lagena spp. Others include Nonion oyae, Bulimina elongate, Bathysiphon spp. and Calcareous indeterminate while the FOBA recovered in the zone include Verneulina spp., Arenaceous indeterminate and Textularia erlandi. The assemblage of this zone suggested Late Eocene (Priabonian) which is equivalent to (P16/P17): Turborotalia cerroazulensis zone of Bolli and Saunders, (1985); (P15 - P17): Po. Semiinvoluta - T. cerroazulensis zone of Berggren et al., (1995); (E14 - E16): G. Semiinvoluta - H. alabamensis zone of Berggren and Pearson (2005); (E14 - E16): G. Semiinvoluta - H. alabamensis zone of Hernitz Kučenjak et al., (2006); (E15 - E16): G. Index - H. alabamensis zone of Wade et al., (2011) and (E15 - E16): G. Index - H. alabamensis zone of Berggren et al., (2018).

Zonal characteristic of Cassigerinella chipollensis zone

Stratigraphic interval: $6715 \mathrm{ft}$. - $7405 \mathrm{ft}$.

Equivalent planktic foraminiferal zone: (P18 /P19): Globorotalia opima opima - Cassigerinella chipollensis/Pseudohastigerina micra and (O1 - O4): P. naguewichiensis - C. angulisuturalis/Ch. cubensis

Age: Early Oligocene (Rupelian). 
Significant microzone events: FDO of Cassigerinella chipollensis at $6715 \mathrm{ft}$. and Spiroplectammina wrightii at $7195 \mathrm{ft}$.

Definition: The top is marked by the FDO of Cassigerinella chipollensis at $6715 \mathrm{ft}$. The base is placed at $7405 \mathrm{ft}$. This interval is categorized by few foraminiferal species. The FOP species recovered in this zone include Cassigerinella chipollensis, Globigerina spp. and Planktic indeterminate. The FOBC recovered within this zone are the calcareous indeterminate while the FOBA recovered in the zone include Textularia 3 (Spiroplectammina wrightii), Verneulina spp., Haplophragmoides spp. and Arenaceous indeterminate. The assemblage of this zone suggested Early Oligocene (Rupelian) which is comparable with (P18 /P19): Globorotalia opima opima-Cassigerinella chipollensis/Pseudohastigerina micra zone of Bolli and Saunders, (1985); (P18 P21a): Ch. cubensis - Pseudohastigerina spp. - Gl. angulisuturalis/Ch. cubensis zone of Berggren et al., (1995); (O1 - O4): P. naguewichiensis - Gl. angulisuturalis/Ch. cubensis zone of Berggren and Pearson (2005); (O1 - O4): P. naguewichiensis - Gl. angulisuturalis/Ch. cubensis zone of Hernitz Kučenjak et al., (2006); (O1 - O4): P. naguewichiensis - Gl. angulisuturalis/Ch. cubensis zone of Wade et al., (2011) and (O1 - O4): P. naguewichiensis - C. angulisuturalis/Ch. cubensis zone of Berggren et al., (2018).

Foram zone: Undiagnostic

Stratigraphic interval: $5590 \mathrm{ft}$ - $6715 \mathrm{ft}$.

Age: Indeterminate

Definition: The top of this zonal interval is placed at $5590 \mathrm{ft}$. (top of analysed interval). The base is marked at $6715 \mathrm{ft}$. defined by the FDO of Cassigerinella chipollensis. This interval is generally barren of foraminiferal species except at depths $5565 \mathrm{ft}$., 5860 $\mathrm{ft}$., $5935 \mathrm{ft}$. and $6295 \mathrm{ft}$. that recorded spot occurrence of foraminiferal species. The FOP species recovered in this zone is Globigerina praebulloides. The FOBA recovered is the Arenaceous indeterminate while the FOBC recovered are the Bathysiphon spp. and Calcareous indeterminate. The age of this zonal interval is indeterminate due to absence of index marker.

Conclusion: The lithostratigraphic unit of the analysed interval is interpreted as the continental and paralic sequences of the Benin and Agbada Formations. A total of twelve foraminiferal species were identified, defined into eleven genera, six subfamilies and eleven families. Planktic foraminiferal species constitute approximately $18 \%$ while the benthics foraminiferal make up $82 \%$ of the total foraminiferal assemblages respectively. The result revealed similar ages of Late Eocene - Early Oligocene. Three informal foraminiferal biozones were proposed - Nonion oyae, Cassigerinella chipollensis and the undiagnostic zone.

Acknowledgment: The authors are grateful to the Management of Nigerian Petroleum Development Company (NPDC) of Nigeria for donating the ditch cutting samples and providing other data for this research work. Also, we sincerely appreciate Mrs Efe Mude of Shell Petroleum Development Company for her support, advice, encouragements and useful corrections rendered during the course of this work.

\section{REFERENCES}

Adeniran, BV, (1997) Quantitative Neogene planktic foraminiferal biostratigraphy of western Niger Delta. NAPE Bull 12, 54-69

Armstrong, H; Brasier, M (2005). Microfossils. (2nd ed) Blackwell Publishing, 350 Main Streat, Malden, USA.

Berggren, WA; Hilgen, FJ; Langereis, CG; Kent, DV; Obradovich, JD; Raffi, I; Raymo, ME; Shackleton, NJ (1995). Late Neogene chronology: new perspectives in high-resolution stratigraphy. Geol. Soc. Am. Bull. 107, 1272-1287.

Berggren, WA; Pearson, PN (2005). A revised tropical to subtropical Paleogene planktonic foraminiferal zonation. J. Foraminiferal Res. 35 (4), 279-298.

Berggren, WA; Bridget, S; Wade, Pearson, PN (2018). Oligocene Chronostratigraphy and Planktonic Foraminiferal Biostratigraphy: Historical Review and current state-of-the-art. Cushman Foundation Special Publication, 46, 2954.

Blow, WH; Banner, FT (1962). The mid-Tertiary (Upper Eocene to Aquitanian) Globigerinaceae. In, Eames, F. E., Banner, F. T. , Blow, W. H. \& Clarke, W. J. (eds) Fundamentals of mid-Tertiary Stratigraphical Correlation. Cambridge University Press, Cambridge. 61-151.

Blow, WH (1969). Late Middle Eocene to Recent planktonic foraminiferal biostratigraphy. In Bronnimann, P. and Renz, H. H. (eds.), Proceedings of the First International Conference on Planktonic Microfossils, Geneva, E. J. Brill, Leiden, 1, 199-422. 
Bolli, HM; Saunders, JB (1985). Oligocene to Holocene low latitude planktic foraminiferal, in $\mathrm{H}$. M. Bolli, J. B. Saunders and K. Perch-Nielsen, eds., Plankton stratigraphy. New York, Cambridge University Press, 1, 155-257.

Brasier, MD (1980). Microfossils. University of Hull Press, Kingston-upon-Hull, UK.

Cordey, WG (1968a). A new Eocene Cassigerinella from Florida. Palaeontology.11, 368-370.

Fadiya, SL; Jaiyeola-Ganiyu, FA; Fajemila, OT (2014). Foraminiferal Biostratigraphy and Paleoenvironment of Sediments from well AM-2, Niger Delta. Ife J. Sci. 16 (1), 61-72.

Farouk, S; Faris, M; Ahmad, F; Powell, JH (2015). New microplanktonic biostratigraphy and depositional sequences across the Middle-Late Eocene and Oligocene boundaries in eastern Jordan. GeoArabia, 20 (3), 145-172

Giwa, GO; Oyede, AC; Okosun, EA (2005). Advances in the Application of Biostratigraphy to Petroleum Exploration and Production. Adapted from presentation and $A A P G$ International Conference, Paris, France.

Hernitz Kučenjak, M; Premec Fućek, V; Slavković, R; Mesić, I (2006). Planktonic Foraminiferal Biostratigraphy of the Late Eocene and Oligocene in the Palmyride Area, Syria. Geologia Croatica, 59 (1), 19-39

Huber, BT; Olsson, RK; Pearson, PN (2006). Taxonomy, biostratigraphy, and phylogeny of Eocene microperforate planktonic foraminiferal (Jenkinsina, Cassigerinelloita, Chiloguembelina, Streptochilus, Zeauvigerina, Tenuitella, and Cassigerinella) and Problematica (Dipsidripella). In, Pearson, PN; Olsson, RK; Hemleben, C; Huber, BT; Berggren, WA. (eds) Atlas of Eocene Planktonic Foraminiferal. Cushman Foundation for Foraminiferal Research, Special Publication.41, 461-508.

Loeblich, RA; Tappan, HL (1988). "Foraminiferal genera and their classification". Van Nostrand Reinhold Co.

Nwaejije EC; Obiosio, EO; Hamidu, I (2017). Foraminiferal biostratigraphy and palaeoenvironment of Well 5, OML 34, Niger
Delta, Nigeria. Inter. J. Adv. Sci. Res. Manage. 3 (1), 39-48.

Nayak, KK; Singh, J (2011). Role of Foraminiferal in Establishing the Biostratigraphy and Paleoecology of Paleogene Sediments in Kosamba - Valecha Olpad and Navsari Area in Narmada-Tapti Block of South Cambay Basin, Gujarat, India. Search and Discovery Article \#50415. Adapted from extended abstract presented at GEO-India, Greater Noida, New Delhi, India, Western Onshore Basin, Vadodara (kknayakongc@yahoo.in) 2ONGC, Western Onshore Basin, Vadodara.

Obaje, SO; Okosun, EA (2013). Paleoenvironmental Interpretation of Tomboy Field, Offshore Western Niger Delta, Nigeria. Inter. J. Sci. Technol. 2 (9), 628-638.

Ozumba, MB; Amajor, LC (1999). Evolutionary relationships in some benthic foraminiferal of the Middle to Late Miocene, Niger Delta. Nigeria Assoc. Petrol. Explo. Bull. 14 (1), 157-167.

Pearson, PN; Spezzaferri, S; Huber, BT; Kučera, M (2018b). Taxonomy, biostratigraphy, and phylogeny of Oligocene Cassigerinella. In, Wade, BS; Olsson, RK; Pearson, PN; Huber, BT; Berggren, WA (eds) Atlas of Oligocene Planktonic Foraminiferal. Cushman Foundation for Foraminiferal Res., Special Pub. 46, 481-494.

Petters, SW (1982). Central West African Cretaceous Tertiary benthic foraminiferal and stratigraphy. Palaeontographica Abt. A., 179, 1-104.

Petters, SW (1984). An ancient submarine canyon in the Oligocene - Miocene of the western Niger Delta. Sedimentology. 31, 805-810.

Petters, SW (1995). Foraminiferal biofacies in Nigeria rift and continental margin deltas, in: M.N., Oti and G., Postma (eds.); Geology of Deltas. A. A., Balkema, Rotterdam. 219-235

Saito, T; Bé, AWH (1963). Planktonic foraminiferal from the American Oligocene. Science. 145, 703704.

Sexton, PE; Wilson, PA; Pearson, PN (2006). Palaeoecology of late middle Eocene planktic foraminiferal and evolutionary implications. Marine Micropaleontology. 60, 116. 
Toumarkine, M; Luterbacher, H (1985). Paleocene and Eocene planktic foraminiferal. In H.M. Bolli, JB; Saunders and K. Perch-Nielsen (Eds.), Plankton Stratigraphy. Cambridge University Press, Cambridge, 87-154.

Ukpong, AJ; Ikediasor, KC; Anyanwu, TC; Osung, EW; Ekhalialu, OM (2017). Foraminiferal Biozonation of "well k-27", Greater Ughelli Depobelt, Niger Delta Basin, South Eastern Nigeria EPRA Int. Jour. of Multidisciplinary Res. 3. 2455-3662

Ukpong, AJ; Ekhalialu, OM; Osung, WE; Omoko, EN (2018). Foraminiferal Biozonation and Biochronology of Priabonian - Repulian sediments of the Agbada Formation, Niger Delta. Int. Joul. of Sci. and Res. Pubs, 8(1), 2250-3153.

Usman Abubakar, (2016). Late Oligocene to Early Middle Miocene Foraminiferal Biostratigraphy, Sequence Stratigraphy and Palaeoenvironment of Well - 004 (OML - 34) Niger Delta. A postgraduate dissertation, 1-116.

Weber, KJ (1971). Sedimentological aspects of oil fields in the Niger Delta. Geologies en Mihnboure, 50, 559-575. 